\title{
POMORZANIE \\ W WALCE O POWRÓT POMORZA GDAŃSKIEGO DO POLSKI
} (1918-1920)

\section{Dariusz Ostapowicz}

\author{
VI Liceum Ogólnokształcące \\ im. Obrońców Helu w Gdańsku \\ The Defenders of the Hel Peninsula 1939 \\ VI High School in Gdańsk \\ e-mail: ostapowicz@wp.pl
}

Streszczenie. „Długi” wiek XIX (1772-1920) upłynął na Pomorzu Gdańskim pod władzą zaborcy pruskiego. Na przekór bismarckowskiej germanizacji kształtowała się nowoczesna świadomość narodowa polska, oparta o tradycje walki o niepodległość $(1807,1830,1848,1863)$ i hasła pozytywistyczne, co wpłynęło na postawy Polaków w latach 1918-1920. O połączeniu Pomorza Gdańskiego - Nadwiślańskiego - Prus Zachodnich (niem. Provinz Westpreussen) z odzyskującą niepodległość Polską zadecydowały silne powiązania z powstaniem wielkopolskim i decyzje konferencji pokojowej w Paryżu (1919). Mimo zakazu podejmowania walki na Pomorzu wydanego przez Naczelną Radę Ludową, działały tu różne grupy konspiracyjne na czele z Organizacją Wojskową Pomorza, toczące utarczki z niemieckim Grenzschutzem-Ost, przygotowujące powstanie w Gdańsku na wypadek pojawienia się „Błękitnej Armii” gen. Józefa Hallera, tworzące partyzantkę w Borach Tucholskich. Konspiratorzy wzięli udział w wojnie z Rosją Sowiecką w 1920 r., a symbolem ich zwycięstwa stały się zaślubiny Polski z morzem 10 lutego $1920 \mathrm{r}$.

Słowa kluczowe: Pomorze Gdańskie; konferencja paryska; powstanie wielkopolskie; Organizacja Wojskowa Pomorza; Wolne Miasto Gdańsk; zaślubiny Polski z morzem. 
1. ROZWÓJ POLSKIEJ ŚWIADOMOŚCI NARODOWEJ W PRUSACH ZACHODNICH NA PRZEŁOMIE XIX I XX WIEKU

„Długi” wiek XIX - od lat 70. XVIII do 20. XX wieku upłynął pod znakiem budzącej i rozwijającej się świadomości narodowej w Europie i na porozbiorowych ziemiach polskich. Cezury te pasują do historii Polski i Pomorza Gdańskiego w okresie niewoli narodowej, tym bardziej że na lata 70. XVIII wieku przypada zajęcie Prus Królewskich przez państwo Fryderyka II Hohenzollerna w okresie I rozbioru (1772 r.), a cezurę końcową stanowić mogą np. zaślubiny Polski z morzem w Pucku (10 lutego 1920 r.). Na budzenie i rozwój polskiej świadomości narodowej na Pomorzu wpływ miały m.in. bitwy epoki napoleońskiej w latach 1806-1807, istnienie i obrona napoleońskiego Wolnego Miasta Gdańska, w którym elity (notabene niemieckojęzyczne) zachowały tradycję autonomii, samorządności z czasów I Rzeczypospolitej i regionalnej, kulturowej odrębności od Prus, przemarsz powstańców-emigrantów listopadowych, Wiosna Ludów, pomoc powstańcom styczniowym, opór przeciw polityce Kulturkampfu i propagandzie Hakaty oraz specyficzna mentalność podkreślająca przywiązanie do religii katolickiej, moralności, ładu, pracowitości, solidności, oszczędności, solidaryzmu narodowego. „Naród kulturowy”, który jako „wspólnota komunikowania” zderzył się z niemieckim państwem prawa wykluczającym istnienie Polski niepodległej, mógł podjąć działania obronne wykorzystujące pozytywizm środków zmierzających ku romantycznym celom, ale również ulegał kompleksowi niższości, zaściankowości i ksenofobii². Nieprzypadkowo zatem wzorcami osobowymi stały się postaci Floriana Ceynowy, Karola Libelta, księdza Piotra Wawrzyniaka³ .

Symbolem walki o suwerenność i niepodległość Polski są życiorysy rodowitych Pomorzan, Józefa Wybickiego (1747-1822) - pułkownika konfederacji barskiej i autora Mazurka Dąbrowskiego, oraz jego imiennika i prawnuka, Józefa (18661929), doktora medycyny, polityka i ministra II RP. Niepoślednią rolę w procesie kształtowania się polskiej świadomości narodowej odegrała miejscowa inteligencja (przede wszystkim duchowieństwo), której „kuźnią” stało się gimnazjum w Chełmnie lub Seminarium Duchowne w Pelplinie nazywane „Atenami Pomorskimi”,

1 Np. J. Osterhammer, Historia XIX wieku. Przeobrażenie świata, thum. I. Drozdowska-Broering [i in.], Poznań 2013, s. 11-12, 71-72. Autor proponuje cezury od rewolucji przemysłowej do skutków I wojny światowej. Dla historii Polski adekwatne do powyższej propozycji są (za prof. M. Kukielem, Dzieje Polski porozbiorowe, Paryż 1984) lata 1795-1921.

2 S. Byкоwska, Elementy polskiej tożsamości narodowej na Pomorzu od połowy XIX wieku do powstania Drugiej Rzeczypospolitej, „Słupskie Studia Historyczne” 2012, nr 18, s. 119-120, 131.

3 J. BorzyszKowski, Gdańsk i Pomorze w XIX i XX wieku, Gdańsk 1999, s. 122-128. 
a przy nim biskupie progimnazjum Collegium Marianum. Czytelnictwo polskiej prasy (m.in. „Gazety Grudziądzkiej”, „Gazety Toruńskiej”, „Gazety Gdańskiej”) przyczyniło się do rozwoju towarzystw ludowych, banków ludowych, spółdzielni, kółek rolniczych bardzo często kierowanych przez duchowieństwo ${ }^{4}$. Fenomen „cichej rewolucji inteligenckiej" opartej na kapitale wiedzy i wielostronnego działania przyniósł efekt w postaci odzyskania wolności ${ }^{5}$.

Na przykładzie losów kilku konspiratorów pomorskich z lat 1918-1920 można prześledzić drogę Pomorzan ku niepodległości. Ksiądz Józef Dembieński (18791962) i ksiądz ppłk Józef Wrycza (1884-1961) pochodzili z chłopskich rodzin, kształcili się w Chełmnie i Pelplinie, gdzie nauczano w języku polskim, tam wstąpili do tajnego kółka samokształceniowego, tzw. Filomatów pomorskich, którzy kultywowali tradycje powstańcze ${ }^{6}$, i choć wykryci i skazani w procesie toruńskim (1901) nie zaprzestali działalności już jako duszpasterze. Ksiądz Dembieński dostrzegał rolę Kaszubów w umacnianiu polskości na Pomorzu (,[...] chodziło o wyrobienie uświadomionych narodowo działaczy wśród braci kaszubskiej, tak bardzo zagrożonej przez germanizację” - wspominał’). Ksiądz Wrycza związał się z ruchem „młodokaszubów", do których należał inny filomata i późniejszy konspirator Franciszek Kręcki (1883-1940) - prawnik, bankowiec, wydawca czasopisma „Gryf” i prezes gdańskiego „Sokoła”.

Do rangi symbolu urasta legenda, iż na forum konferencji w Paryżu Antoni Abraham (1869-1923) - nazywany „królem Kaszubów” - „stanął przed obliczem tego wysokiego areopagu, który wówczas rozstrzygał o losach pokoju i stanowczym głosem [...] oświadczył, że Kaszubi są Polakami i nie tylko chcą ale muszą należeć do Polski”».

Rok 1920 w stosunku do Pomorza zapisał się w ogólnopolskiej świadomości narodowej przede wszystkim poprzez zaślubiny Polski z morzem, poprzedzone wysiłkiem dyplomacji polskiej na forum konferencji pokojowej w Paryżu; w tym kontekście niknie pamięć o dłuższym w istocie procesie powrotu do Macierzy zawierającym elementy konspiracji i walki zbrojnej (jeżeli pojawiają się na kartach historiografii, to jako element powstania wielkopolskiego z lat 1918-1919)9.

4 Tamże, s. 136-137; S. BүкоwsKA, Elementy, s. 126-129.

5 A. NowaK, Rozważania o niepodległości 1018-1918-2018, „Arcana”, 2018, nr 143, s. 25.

6 J. Dembieński, Radości mało - goryczy dużo. Pamiętnik Pomorzanina z lat 1879-1920, oprac. A. Bukowski, Warszawa 1985, s. 85-86: kółka 3-5 osobowe świętowały rocznice 3 Maja, 29 Listopada, 22 Stycznia; K. Korda, Ks. ppłk Józef Wrycza (1884-1961). Biografia historyczna, Gdańsk 2016, s. 32: przysięga na powstańczy krzyż z 1863 r.

7 J. DeMBIEŃski, Radości mało - goryczy dużo, s. 104.

8 Tamże, s. 237.

9 C. Brzoza, Polska w czasach niepodległości i II wojny światowej (1918-1945), w: Wielka historia Pol$s k i$, red. S. Grodziski [i in.], t. V, cz. 1, Warszawa-Kraków 2003, s. 23-25; R. WAPIŃsKI, Lata nadziei 
Omawiany w artykule problem zmagań Pomorzan o powrót Pomorza Gdańskiego do odradzającej się Rzeczypospolitej - uwzględniając genezę zjawiska rozpatrywać można zwłaszcza od końca I wojny światowej (1918) po początek funkcjonowania Wolnego Miasta Gdańska (1920) i przejmowanie Pomorza Gdańskiego przez Wojsko Polskie (styczeń-luty 1920). W tle tych wydarzeń rozgrywały się przykłady zmagań Polaków z Pomorza z najazdem bolszewickim w $1920 \mathrm{r}$. Wydarzenia związane z zaproponowanymi cezurami stanowią merytoryczny zakres niniejszej pracy. Najnowszy stan badań, przegląd źródeł i postulaty badawcze zaprezentował prof. Przemysław Olstowski ${ }^{10}$.

Pewnego wyjaśnienia wymaga różnorodność stosowanej nomenklatury w stosunku do opisywanego obszaru. Spośród wielu nazw ${ }^{11}$ używanych w historiografii najczęściej występują: Pomorze Gdańskie, Prusy Królewskie, Prusy Zachodnie (niem. Westpreussen), Pomorze Nadwiślańskie. Wynika to z faktu, że w latach 1918-1920 polscy konspiratorzy działali w granicach administracyjnych Prus Zachodnich z 1878 r., tworzących dwie rejencje - w Gdańsku i Kwidzynie. Nazwa Pomorze Nadwiślańskie opierająca się na kryterium geograficznym - dolny bieg i ujście Wisły na północy oraz Bory Tucholskie na południu, zasadniczo pokrywała się z granicami wytyczonymi w 1878 r., podczas gdy Pomorze Gdańskie (województwo pomorskie) w granicach II RP było terytorialnie mniejsze i w Dwudziestoleciu zmieniało swoje granice ${ }^{12}$. Pojęcie Kresów Pólnocnych i Zachodnich jest natomiast zbyt ogólne, obejmuje bowiem obszary „często nie dające się wykreślić w postaci linearnej, a nie zawsze potwierdzone strukturą etnograficzną" - pisze prof. Wojciech Wrzesiński i dodaje, że pogranicze lepiej oddaje specyfikę relacji polsko-niemieckich ${ }^{13}$.

(1918-1939), w: Dzieje Pomorza Nadwiślańskiego od VII wieku do 1945 roku, red. W. Odyniec, Gdańsk 1978, s. 423-425.

${ }^{10}$ P. Olstowski, Organizacja Wojskowa Pomorza (1918-1920). Polska konspiracja zbrojna w okresie poprzedzajacym powrót Pomorza do Polski. Pytania i postulaty badawcze, „Rocznik Toruński”, 46 (2019), s. 7-33.

${ }^{11}$ Prof. J. Borzyszkowski wprowadził na karty historiografii regionalnej określenie Polskie Pomorze (zob. J. Borzyszkowski, O historii literatury kaszubskiej i jej twórcach, Gdańsk 2011, s. 23), choć ta nazwa spotkała się z polemiką autorów Dziejów Pomorza Nadwiślańskiego, s. 5 (,termin jest również za wąski”). Autor posługuje się również nomenklaturą: Pomorze Kaszubskie i Wielkie, zob. TENŻE, Ideał państwa polskiego - marzenia Pomorzan a rzeczywistość w $1920 \mathrm{r}$., w: Pomorskie drogi do Niepodległej, red. J. Borzyszkowski i C. Obracht-Prondzyński, Gdańsk 2018, s. 143.

${ }^{12}$ Dzieje Pomorza Nadwiślańskiego, s. 8, 428.

${ }^{13}$ W. Wrzesiśski, Kresy czy pogranicze? Problem ziem zachodnich i pótnocnych w polskiej myśli politycznej XIX i XX w., w: Między Polska etniczna a historyczna, red. W. Wrzesiński (seria: Polska myśl polityczna XIX i XX wieku, t. 6), Wrocław 1988, s. 120-121. 
2. GENEZA, STRUKTURY, DZIAŁALNOŚĆ KONSPIRACJI POMORSKIEJ ZMAGANIA O PRZYSZŁOŚĆ POMORZA GDAŃSKIEGO

W LATACH 1918-1920

Okres przed i w czasie I wojny światowej przyniósł postulaty - sygnalizowane z wielu środowisk polskich - odbudowy Polski z granicą opartą o Bałtyk, choć, póki co, były nieprecyzyjne ${ }^{14}$. Podkreślano konieczność włączenia Prus Królewskich-Prus Zachodnich do odrodzonej Polski. „Kwestia bytu terytorium narodowego polskiego Prus Zachodnich ma pierwszorzędne znaczenie dla narodu polskiego: od rozwiązania tej kwestii zależy los Polski" - zapisano w nocie do komisji Jules'a Cambona w Paryżu, kreśląc zarazem niebezpieczeństwo pozostawienia „korytarza pomorskiego" rozdzielającego terytoria Republiki Niemieckiej ${ }^{15}$. Konkretnym przykładem polskich aspiracji do tych terenów był dekret Naczelnika Państwa z 28 listopada 1918 r. o wyborach do Sejmu Ustawodawczego ziem polskich z zaboru pruskiego po tzw. linię Dmowskiego ${ }^{16}$.

Środowiska filomackie na Pomorzu kontynuowały działalność konspiracyjną poprzez struktury Związku Młodzieży Polskiej „Zet”, Towarzystwa Tomasza Zana (m.in. w Chojnicach, Chełmnie, Wejherowie, Brodnicy, Świeciu - nieprzypadkowo będzie to teren aktywności patriotycznej w 1919 r.) i nawiązały kontakt z Polskimi Drużynami Strzeleckimi. Po wybuchu I wojny światowej w Poznaniu zawiązano tajny Komitet Międzypartyjny, w którego składzie reprezentantami Prus Zachodnich zostali m.in.: prawnik, dr Stefan Łaszewski (1862-1924), ksiądz Feliks Bolt (1864-1940) - filomata i spółdzielca oraz ksiądz Antoni Wolszlegier (1853-1922), poseł w Reichstagu ${ }^{17}$. Na nastroje patriotyczne i rewolucyjne oddziaływała represyjna polityka władz niemieckich (np. rewizje w Brodnicy w 1914 r.), aresztowania księży, działaczy społecznych, rewizje wśród ziemian, narastające problemy gospodarcze, brak rąk do pracy, kontakty z Polakami-jeńcami z armii

${ }^{14}$ S. WierzchosŁawski, Pomorze Nadwiślańskie w polskiej myśli politycznej XIX wieku, w: Pomorskie drogi, s. 33 (poglądy Wojciecha Korfantego i Mariana Seydy), s. 38 (poglądy Wiktora Kulerskiego); R. WAPIŃsKi, Świadomość polityczna w Drugiej Rzeczypospolitej, Łódź 1989, s. 156-163 (m.in. poglądy Marii Dąbrowskiej, Eugeniusza Romera, Wacława Nałkowskiego, Jana Ludwika Popławskiego), s. 181 (o Akcie 5 Listopada), s. 200-201 (postulaty R. Dmowskiego z lat 1914-1917 dotyczące Prus Zachodnich).

${ }^{15}$ Nota delegacji Polskiej do Jules'a Cambona z 28 lutego 1919 r., cyt. za: Polska w latach 1918-1939. Wybór tekstów źródłowych do nauczania historii, red. W. Wrzesiński, oprac. K. Kawalec, L. Smołka, W. Suleja, Warszawa 1986, s. 60.

${ }^{16}$ Tamże, s. 229.

${ }^{17}$ R. WAPIŃski, Pomorze Nadwiślańskie w okresie II Rzeszy (1871-1918), w: Dzieje Pomorza Nadwiślańskiego, s. 417-418. 
rosyjskiej, antypolska działalność Komisji Kolonizacyjnej, głód w miastach, braki w zaopatrzeniu, co wywoływało żywiołowe demonstracje, np. w Chełmży (11, 14-15 maja 1917 r.; aresztowano 31 Polaków), zjawiska bandytyzmu i korupcji. Na nasilenie postaw patriotycznych wpłynęły również obchody setnej rocznicy śmierci Tadeusza Kościuszki w 1917 r. oraz proklamacja środowisk prasy polskiej z 11 października 1918 r. żądająca włączenia zaboru pruskiego do Polski ${ }^{18}$. Bezpośrednim impulsem do podjęcia działań niepodległościowych była rewolucja niemiecka rozpoczęta w listopadzie $1918 \mathrm{r} .{ }^{19} \mathrm{Z}$ inicjatywy poznańskiej Naczelnej Rady Ludowej (NRL) niemieckie Rady Delegatów Robotniczych i Żołnierskich zaczęły być zasilane przez Polaków, którzy czasami sami wręcz tworzyli własne rady, np. w Brodnicy, Chełmnie, Kościerzynie, Kartuzach, zatem tam, gdzie przewaga ludności polskiej była wyraźna. W Chmielnie kowal Regliński i organista Bukowski ogłosili lokalną polską republikę ${ }^{20}$. W Brodnicy konspiracyjne komitety obywatelskie przekształciły się w Powiatowe Rady Ludowe podporządkowane NRL. Zaistniały sytuacje, w których obie rady - ludowa i robotnicza ściśle ze sobą współdziałały, a nawet miały jednego kierującego. Przykładem jest dr Paweł Ossowski (1878-1939) w Chełmnie - filomata, adwokat, społecznik, współtwórca gazety „Nadwiślanin”. Od 13 grudnia 1918 r. na Pomorzu Nadwiślańskim działał Podkomisariat NRL na Prusy Królewskie, Warmię i Pomorze z siedzibą w Gdańsku, na czele z dr. Stefanem Łaszewskim. Późną jesienią 1918 r. Polacy zaczęli tworzyć na obszarze Prus Zachodnich straże ludowe, często na bazie „Sokoła” i związków wojackich (kombatanckich) „Jedność”. Jednocześnie w ich, jawnych i półjawnych, szeregach formowała się konspiracja pomorska - Organizacja Wojskowa Pomorza (OWP), która powstała 30 grudnia 1918 r., kierowana przez dr. Franciszka Kręckiego i jego zastępcę, dr. Józefa Wybickiego. Niepełne źródła nie pozwalają na precyzyjne odtworzenie jej struktur, które - według rozbieżnych naukowych poglądów - mogły liczyć od czterech do siedmiu okręgów, każdy dzielący się na sześć do dziesięciu obwodów w 156 miejscowościach, a liczebność OWP łącz-

${ }^{18}$ M. WoJciechowsKi, Ruch polski na Pomorzu Gdańskim w latach pierwszej wojny światowej (19141918), „Zapiski Historyczne”, 39 (1974), z. 3, s. 221, 229, 232, 234; T. CIEŚLAK, Przeciw pruskiej przemocy. Walka o ziemię na Pomorzu na przełomie XIX i XX w., Warszawa 1959, s. 149, 151, (w 1918 r. w budżecie pruskim na cele Komisji przeznaczono 2656614 marek - s. 152); T. KRZEMIŃsKI, Pierwsza wojna światowa - pomorskie doświadczenie codzienności, w: Pomorskie drogi, s. $76-77,85,91$.

${ }^{19}$ Ważnym przełomem w postawach Polaków na Pomorzu Gdańskim był Akt 5 Listopada 1916 r., nie tyle przez swoją treść, ile ze względu na przedłużającą się wojnę i rysującą się perspektywę klęski Niemiec - sugeruje prof. P. Olstowski, TENŻe, Działalność Pomorzan na rzecz powrotu Pomorza do Polski w latach 1918-1920, w: Pomorskie drogi, s. 94.

${ }^{20}$ R. WAPIŃsKi, Lata nadziei (1918-1939), w: Dzieje Pomorza Nadwiślańskiego, s. 422. 
nie ze strażami ludowymi według ostrożnych szacunków nie przekraczała kilku tysięcy ludzi ${ }^{21}$.

Na zaniechanie podjęcia walki zbrojnej miały wpływ różne czynniki - przewaga wojska niemieckiego, ich czujność po wybuchu powstania wielkopolskiego, słabość organizacyjna OWP, rozproszenie ludności polskiej, nieliczna kadra przywódcza. Na podjęcie działań zbrojnych zgadzano się wyłącznie w ramach wsparcia marszu „Błękitnej Armii” gen. Józefa Hallera (1873-1960) z Gdańska przez Pomorze. Wojciech Korfanty (1873-1939) miał wyznaczyć termin wybuchu na 19 grudnia 1918 r., ale wojska Hallera nie przybyły, zatem 3 stycznia 1919 r. NRL podjęła decyzję o rezygnacji z działań zbrojnych. Według niezrealizowanych projektów gen. Józefa Dowbora-Muśnickiego (1867-1937), miała to być jedynie antyniemiecka dywersja na pograniczu Wielkopolski i Pomorza, ale ofensywa powstańcza została zatrzymana pod Gniewkowem, nie dochodząc do granic prowincji ${ }^{22}$. Specyfikę sytuacji na Pomorzu trafnie podsumował pamiętnikarz:

\begin{abstract}
Jak na całym Pomorzu, tak i w powiecie chojnickim powstała pod egidą Naczelnej Rady Ludowej w Poznaniu tajna organizacja wojskowa z siedzibą w Chojnicach pod komendą Szpręgi [...]. Celem tej tajnej organizacji było utrzymywanie ścisłej ewidencji tych, którzy byli gotowi i zdolni stanąć do walki, oraz zasobów posiadanej broni, także utrzymywanie stałego pogotowia wojennego. [...] Pomorzanie palili się do walki, czekali atoli albo na wylądowanie wojsk Hallera, albo na posunięcie się zbrojnych oddziałów poznańskich aż do Torunia i Bydgoszczy. Niestety, ani do jednego ani do drugiego nie doszło. Tymczasem wmieszała się w tę sprawę koalicja i zakazała dalszego posuwania się frontu, zapewniając, że losy Pomorza będą sprawiedliwie rozstrzygnięte ${ }^{23}$.
\end{abstract}

Ludność niemiecka nie czekała bezczynnie na niekorzystny dla integralności Republiki Weimarskiej rozwój wypadków. Powstawały ochotnicze oddziały paramilitarne: Regnost (Reserve Grenzschutz-Ost), Bürgerwehr, Einwohnerwehr (,straż

${ }^{21}$ P. Olstowski, Organizacja Wojskowa, s. 124-128: okręg 1 (Torun - Leon Czarliński), okręg 2 (Grudziądz - Jerzy i Bolesław Donimirscy), okręg 3 (Starogard lub Lubawa - Bolesław Ossowski i Teofil Rzepnikowski), okręg 4 (Puck-Czersk, Bolesław Lipski i Augustyn Szpręga), okręg 5 (Starogard - Mieczysław Marchlewski), okręg 6 (Bytów - Aleksander Wysocki i Bernard Wera), okręg 7 (Ełk -Władysław Pieniężny).

${ }^{22}$ M. Wojciechowski, Dwie koncepcje powrotu Pomorza Gdańskiego do Polski w latach 1918-1919, „Zapiski Historyczne”, 35 (1970), z. 1, s. 71-72, 75, 79; Powrót. Dokumentacja ustanowienia suwerenności polskiej na Pomorzu w latach 1918-1920, wybór J. Bełkot, M. Wojciechowski, Toruń 1988 , s. 11.

${ }^{23}$ J. DeMBIEŃSKI, Radości mało - goryczy dużo, s. 322-323. 
obywatelska”) złożone z kombatantów i osób cywilnych ${ }^{24}$. Propagandowe zapowiedzi o utrzymaniu porządku, bezpieczeństwa, spokoju, ładu ,przed polskimi rabunkami” nie szły w parze z rzeczywistością, w której to strona niemiecka szerzyła terror.
Aufruf!
Kameraden! Mitbürger! Volksgenose!
Danzig und Westpreussen sind in Gefahr!
[...] Unserer Heimatprovinz droht d. gleiche Schicksal wie der Provinz Posen. [...]
Sollen wir jetzt willen und tatenlos vor polnischen Machtansprüchen kapitulieren? [...]
Wir fordern daher alle deutschgesinnten Männer, die bereit sind, freiwillig Leib und
Leben für unsere Heimatprovinz einzusetzen, auf, sich umgehend für den die Siche-
rung in der ganzen Provinz ausführenden.
Grenzschutz-Ost (Abteilung für Westpreussen) zu melden.
[...] Wir wollen nur deutsche Städte und Gaue schützen, deutsche Kornkammern und Kulturstätten vor räuberischen Ubergriffen bewahren. [...]
Wir müssen dem deutschen Ostheer den Weg ins Innere Deutschlands offen halten. Ist Westpreussen verloren, so ist ihm der letzte Weg zur Heimat versperrt! [... $]^{25}$.

To nie jedyny przykład niemieckiej propagandy, wzywającej niemieckich obywateli Provinz Westpreussen do Grenzschutzu-Ost i zalecającej zachowanie terytorialnego status quo. „Dobrowolnie naszych ziem Polakom nie wydamy. Nie zgodzimy się też na lądowanie wojsk Hallera w Gdańsku. [...] wzywamy znowu nasz lud polski, ażeby się zachowywał spokojnie" - takie niemieckie wezwania przedrukowała prasa polska w marcu 1919 r. ${ }^{26} \mathrm{Na}$ potwierdzenie represyjnej, antypolskiej polityki władz Provinz Westpreussen służy artykuł polskiej gazety z Berlina opisujący ówczesną sytuację ludności polskiej:

Położenie w Prusach Zachodnich.

Na podstawie dostarczonych nam świeżo dokumentów z Prus Zach. stwierdzamy, że w ciągu ostatnich kilku tygodni nadużycia ze strony Grenzschutzu, popełnione na bezbronnej ludności polskiej wzmogły się niesłychanie. Militaryzacja kraju osiągnęła najwyższy stopień. Polacy mają podwójnie do cierpienia, bo zarówno wskutek celowych zarządzeń antypolskich władz wojskowych, reprezentujących staro pruski system reakcyjny, jak wskutek zdziczenia i bezkarności żołnierzy Heimatschutzu. Wszelka swoboda ruchów ludności polskiej jest skrępowana, zebrań żadnych nie wolno urządzać.

\footnotetext{
${ }^{24}$ P. Olstowski, Działania Pomorzan, s. 100-101.

${ }^{25}$ O. Lienau, Die Geschichte der Studentenkompanie auf dem Hagelsberg zu Danzig, Danzig 1929, s. 13.

${ }^{26}$ Niemcy zbroja się do walki z Polakami, „Gazeta Toruńska”, nr 74, 2 IV 1919, s. 3; Zapowiedź rzezi, „Gazeta Toruńska”, nr 66, 22 III 1919, s. 1; Archiwum polityczne Ignacego Paderewskiego, oprac. W. Stankiewicz, A. Piber, t. II (1919-1921), Wrocław 1974, s. 134 (rozkaz niemiecki z 24 lutego 1919 przytoczony przez I.J. Paderewskiego w liście z 6 maja 1919).
} 
Nawet zebrania towarzystw śpiewu są zakazane. [...] Wypadki rewizji u Polaków, połączone regularnie z najbezczelniejszymi kradzieżami, są w Prusach Królewskich na porządku dziennym. [...] Wszelkie informacje potwierdzają rozpaczliwe położenie ludności polskiej w Prusach Królewskich i czynią natychmiastową pomoc niezbędną ${ }^{27}$.

Spontaniczne walki wybuchły w Czersku, gdy w święto Trzech Króli 6 stycznia 1919 r. żołnierze Grenzschutzu prowokacyjnie zrywali z ubrań modlących się ludzi polskie emblematy. Tego dnia doszło do walki. Gdy demonstranci opanowali ratusz, pocztę i dworzec, rozpoczęła się strzelanina z Grenzschutzem, a po stłumieniu ruchu - aresztowania. Nie udało się opanowanie Torunia przez tajny Komitet dla Wyzwolenia Pomorza pod kierunkiem dr. Ottona Steinborna (1868-1936). Na skutek aresztowań plan ataku przewidziany na 1 lutego 1919 r. załamał się, ale 28 stycznia 1919 r. wybuchły walki w Chełmży. Naprzeciw wkraczającego do miasta batalionu Grenzschutzu pod dowództwem Gerharda Rossbacha wspartego przez artylerię przywódcy powiatowej rady ludowej: Adam Czarliński (1870-1956) i ksiądz Józef Wrycza mogli przeciwstawić nieskoordynowaną akcję kończącą się przegraną. Niemieckie władze wojskowe wydały rozkaz o aresztowaniach podejrzanych Polaków ${ }^{28}$ (co nie ominęło m.in. księdza J. Wryczy).

We wtorek 28-I- doszła wiadomość do Chełmży, że w środę 29-go przybędzie do Chełmży Grenzschutz. [...] Podczas obrad [rady miasta] zajechał przed ratusz samochód od Grenzschutzu z oficerem i 3 żołnierzami. W tej chwili wkroczyło kilku ludzi z straży bezpieczeństwa, którzy przed ratuszem patrolowali, na stopnie samochodu, zabrali oficerowi i żołnierzom broń i uwięzili ich w sklepie. Oficer z żołnierzami zdołał zbiec.

Napastnicy udali się zabranym samochodem za nimi w pościg, spotkawszy za miastem oddział Grenzschutzu zaczęli go ostrzeliwać. Grenzschutz odpowiedział ogniem karabinowym, przyczem jeden z atakujących poległ, drudzy uciekli. Dla postrachu dał Grenzschutz kilka strzałów armatnich do miasta, pękający szrapnel zabił małą dziewczynkę na ulicy. Wieczorem ogłoszono stan oblężenia $[\ldots]^{29}$.

Niemcy wprowadzili stan oblężenia nie tylko w Chełmży, ale również w okolicznych wsiach, m.in. w Ostaszewie, Bruchnowie, Biskupicy, Dębinach, Kamionkach ${ }^{30}$. Uprzedzili wybuch powstańczy w Brodnicy (9 stycznia); powstańcy zrezygnowali

27 „Dziennik Berliński”, nr 30, 21 III 1919, cyt. za: Powrót. Dokumentacja, s. 50.

${ }^{28}$ W sprawie bezprawnego aresztowania Polaków, „Gazeta Toruńska”, nr 34, 13 II 1919, s. 1; Niemcy „przystąpią natychmiast do aresztowania [...] wybitnych osób biorących udział w życiu politycznym narodu" - list do J. Hallera z 3 kwietnia 1919: Archiwum polityczne, s. 81.

${ }^{29}$ List L. Czarlińskiego z Chełmży do Podkomisariatu NRL w Gdańsku, 1 II 1919, cyt. za: Powrót. Dokumentacja, s. 46.

${ }^{30}$ Położenie w Prusach Zachodnich, „Gazeta Toruńska”, nr 34, 13 II 1919, s. 1. 
z akcji w Bydgoszczy; wrzało w Świeciu, Kościerzynie, Pucku, Tucholi, pokojowe wiece odbyły się w Brusach i Gdyni ${ }^{31}$. W powiecie kwidzyńskim, po obu brzegach Wisły miejscowi Polacy utworzyli namiastkę polskiej państwowości, Republikę Gniewską ( 7 lipca 1919-27 stycznia 1920), której celem był opór przeciwko Niemcom i chęć powrotu do Macierzy. Rada Ludowa kierowana przez księży: Antoniego Wolszlegiera i Aleksandra Kupczyńskiego (1873-1941) kierowała polskim życiem społeczno-politycznym. Z jej inicjatywy powołano Straż Ludową prowadzącą utarczki z Grenzschutzem (przekształconą następnie w Tajną Organizację Wojsk Polskich na Pomorzu).

Tymczasem już od 1917 r. wielu dezerterów z armii niemieckiej ukrywało się w naprędce skleconych bunkrach w Borach Tucholskich i stąd nazywani byli przez ludność „bunkrowcami”. Byli wśród nich Wincenty Szpica, Franciszek Kleinschmidt, Paweł Otton, Maksymilian Kitowski, Szarmach, a zwłaszcza August i Bolesław Gnacińscy, o których „samorzutnej ruchawce” partyzanckiej wspominał ksiądz Dembieński ${ }^{32}$. Współcześni historycy stawiają jednak pytanie, czy kłusowników i rabusiów parających się napadami i morderstwami na cywilną ludność niemiecką, ale równocześnie uczestników zbrojnych utarczek z Grenzschutzem można nazwać partyzantką? $?^{33}$

Dnia 19 października 1919 r. gen. Józef Haller mianowany został dowódcą tzw. Frontu Pomorskiego. Służyli w nim Pomorzanie, często werbowani jako ochotnicy przez OWP do powstania wielkopolskiego i przedzierający się spod zaboru pruskiego na tereny objęte powstaniem lub do Polski. W skład frontu wchodziły dwie dywizje piechoty, brygada jazdy i inne wydzielone jednostki Wojska Polskiego. Jednostkom Dywizji Strzelców Pomorskich pod dowództwem płk. Stanisława Skrzyńskiego nieprzypadkowo nadano nazwy związane z Pomorzem, zaś numery pułków nadano później, w marcu 1920 r. (63. Toruński Pułk Piechoty, 64. Grudziądzki Pułk Piechoty, 65. Starogardzki Pułk Piechoty, 66. Kaszubski Pułk Piechoty im. Marszałka Józefa Piłsudskiego ${ }^{34}$ ). 11. Dywizji Piechoty gen. Jakuba Gąsieckiego podporządkowano 21. Brygadę Piechoty (46. i 47. Pułki Strzelców Kresowych) oraz 22. Bry-

${ }^{31}$ R. WAPIŃski, Lata nadziei, s. 425-426; W. ZAWAdZKI, Pomorze 1920, Warszawa 2015, s. 16-26; K. Korda, Ks. ppłk Józef Wrycza, s. 100-102; M. WoJCIECHOwski, Dwie koncepcje, s. 81-82.

32 J. DemBiEŃski, Radości mało - goryczy dużo, s. 331-346 (80-osobowy oddział zajmował się rabunkami wśród Niemców i walką z Grenzschutzem).

${ }^{33}$ J. BorzyszKowski, Partyzantka Borów Tucholskich XX w. - mity a rzeczywistość, w: Ludzie, idee, wojny. Studia z dziejów Europy środkowo-wschodniej, red. T. Kawski, J. Maciejewski, Bydgoszcz 2009, s. 308-316.

${ }^{34}$ M. HIRSCH, Nieustraszeni. 66. Kaszubski Pułk Piechoty im. Marszałka Józefa Pitsudskiego 1919-1939, Gdańsk 2017, s. 16, s. 23: Delegacja pułku będąc w Warszawie poprosiła J. Piłsudskiego, by został szefem pułku. Plutonowy Jan Hirsch z tej okazji przemówił po kaszubsku: „Më wiedno bëlë Pòlakami”. 
gadę Piechoty (48. i 49. Pułki Strzelców Kresowych i 11. Pułk Artylerii Polowej). V Brygada Jazdy płk. Stefana Suszyńskiego (w składzie: 2. Pułk Szwoleżerów Rokitniańskich, 1. Pułk Ułanów Krechowieckich, 12. Pułk Ułanów Podolskich). Pod rozkazami gen. Józefa Hallera znalazły się również inne wydzielone jednostki: m.in. 3. Pułk Strzelców Podhalańskich, 42. Pułk Strzelców Kresowych, baterie z pułków artylerii ciężkiej i polowej, kompanie batalionu saperów, 1. Batalion Morski, 5 pociągów pancernych i Flotylla Wiślana. Działania wspierała IV Grupa Lotnicza ${ }^{35}$.

Na mocy traktatu wersalskiego i szczegółowych umów wojskowo-cywilnych zawartych między stroną polską i niemiecką ${ }^{36}$ od 17 stycznia 1920 r. na terytoria przyznane Rzeczypospolitej Polskiej wkraczało Wojsko Polskie. Dla Polaków z Pomorza, jak wyznał ksiądz Józef Dembieński, była to „najradośniejsza, najsłoneczniejsza chwila w życiu" ${ }^{37}$. Zgodnie z przyjętym harmonogramem, zajmowanie terytoriów trwało od 18 stycznia do 10 lutego 1920 r. Dywizja Strzelców Pomorskich maszerowała po prawej stronie Wisły, 11. Dywizja Piechoty - po lewej. Najwcześniej Wojsko Polskie wkroczyło do Torunia, Brodnicy, Nowego Miasta (18-19 stycznia) i stamtąd stopniowo posuwało się na północ, opanowując Chełmno i Wąbrzeźno (20-22 stycznia), Grudziądz i Sępólno (23 stycznia), Świecie i Gniew (25-28 stycznia), Tucholę i Starogard Gdański (29 stycznia), Tczew, Kościerzynę, Chojnice, (30-31 stycznia), Kartuzy, Wejherowo, Puck (4-10 lutego) ${ }^{38}$.

Po przekroczeniu linii demarkacyjnej 63. Toruński Pułk Piechoty (w którym służył ksiądz mjr Józef Wrycza) entuzjastycznie witany przez Polaków - mieszkańców Pomorza Nadwiślańskiego ${ }^{39}$, stoczył potyczkę pod Gniewkowem (17 stycznia 1920) tracąc 10 rannych i zabitego, plut. Gerharda Piątkowskiego ${ }^{40}$. W Toruniu w czasie wejścia Wojska Polskiego do miasta we wszystkich kościołach przy biciu dzwonów odśpiewano Te Deum ${ }^{41}$.

W Grudziądzu polska ludność miasta czekając na wejście Wojska Polskiego zaczęła rozbijać pomniki Bismarcka i Wilhelma I. Na polecenie brytyjskiej misji

${ }^{35}$ W. ZawadzKi, Pomorze 1920, Warszawa 2015, s. 31-33, 38.

${ }^{36}$ Powrót. Dokumentacja, s. 19, 94-100 (umowa cywilne i wojskowe z 24-26 listopada 1919 r.).

37 J. DeMBIEŃsKi, Radości mało - goryczy dużo, s. 347.

${ }^{38}$ C. Obracht-Prondzyński, K. Korda, Powrót Pomorza w Granice Rzeczypospolitej. W setna rocznice 1920-2020, Gdańsk 2020, s. 92.

${ }^{9}$ Witaj nam Matko Polsko!, „Gazeta Toruńska”, nr 14, 15 I 1920, s. 1; Witaj nam Polski Żolnierzu!, „Nadwiślanin”, nr 18, 23 I 1920, s. 2; Podróż generała Hallera do miast odzyskanych, „Gazeta Toruńska”, nr 31, 8 II 1920, s. 1; M. Hirsch, Nieustraszeni, s. 114; Powrót. Dokumentacja, s. 119-123 (odezwa S. Łaszewskiego z 18 stycznia 1920 r.).

40 Pierwszy pogrzeb polskiego żotnierza Pomorzanina, „Gazeta Toruńska”, nr 20, 25 I 1920, s. 1: w kościele św. Jana w Toruniu mszę św. odprawił ks. J. Wrycza; poległego żegnali matka, siostra, burmistrz i żołnierze.

${ }^{41}$ M. HirsCh, Nieustraszeni, s. 26. 
wojskowej żołnierze polscy mieli przywrócić porządek w mieście, choć czynili to z niechęcią („,To po to było nam przekradać się stąd do Poznania, tam ćwiczyć, by tu po powrocie chronić szwabskie pomniki?" - narzekali ${ }^{42}$ ).

Generał Józef Haller oddał cześć bohaterom z OWP, pisząc w specjalnym rozkazie: „Wyrażam im za ich niezmordowaną pracę, która osiągnęła tak wspaniałe rezultaty, swe uznanie i podziękowanie" (rozkaz z 9 marca 1920 r.) ) $^{43}$.

Weterani zmagań o łączność Pomorza Gdańskiego z Polską założyli Towarzystwo Kombatantów i Wojaków Okręgu Korpusu VIII oraz Związek Hallerczyków. Ksiądz Józef Wrycza współorganizował w parafii w Wielu, gdzie pracował, te organizacje i współtworzył znamienną rezolucję:

\footnotetext{
My wojacy i powstańcy Kaszubi-Polacy [...], tworząc straż nad Wisłą i Bałtykiem, ślubujemy wytrwać na posterunku do ostatniej kropli krwi w sercach naszych polskich.

Tak nam dopomóż Bóg! [...]

Czujcie tu ze serca toni Skład nasz Apostolski.

Nie ma Kaszub bez Polonii, A bez Kaszub Polski i Wolności! ${ }^{44}$
}

\section{POLACY I NIEMCY WOBEC UTWORZENIA WOLNEGO MIASTA GDAŃSKA}

Inspirującym impulsem dla Polaków w Gdańsku była wizyta Ignacego Jana Paderewskiego (1860-1941), który 25 grudnia 1918 r. przejeżdżał przez Gdańsk zmierzając do Poznania. Konferował wówczas z działaczami polskimi, tworzącymi zręby organizacji niepodległościowych, w tym z dr. Franciszkiem Kubaczem (1868-1933) ${ }^{45}$.

Polacy utworzyli w Gdańsku Radę Żołnierzy Polaków, która podlegała lokalnemu Podkomisariatowi Rady Ludowej z dr. Stefanem Łaszewskim na czele, NiemcyRadę Robotniczo-Żołnierską ${ }^{46}$. Niemcy gdańscy kilkakrotnie protestowali wobec perspektywy odłączenia miasta od Republiki Weimarskiej, uczestnicząc w maso-

${ }^{42}$ Cyt. za: B. Skaradziński, Sąd boży 1920 roku, Warszawa 1995, s. 131; J. Brzoza, Polski rok 1919 , Londyn 1988, s. 286, 288.

${ }^{43}$ Cyt. za: C. Obracht-Prondzyński, K. Korda, Powrót Pomorza w granice Rzeczypospolitej. W setna rocznicę 1920-2020, Gdańsk 2020, s. 53.

${ }^{44}$ Rezolucja Towarzystwa Powstańców i Wojaków, Wiele, 16 marca 1925 r., cyt. za: K. KordA, Ks. ppłk Józef Wrycza, s. 181. „Ksiądz Wrycza był fanatykiem endecji” (s. 211), Pierwszego Marszałka Polski Józefa Piłsudskiego nazwał „wybitnym przeciwnikiem” (s. 217), współtworzył konspirację „Gryf Pomorski” w 1940 r. (s. 264).

${ }^{45}$ C. Skonka, Wizyta I. J. Paderewskiego w Gdańsku, „Pieśń Skrzydlata”, 18(2010), nr 2, s. 30.

${ }^{46}$ „Nadwiślanin”, nr 4, 4 VII 1919, s. 1; „Nadwiślanin”, nr 1, 12 VI 1919, s. 1 („hakatyści na czele Volksratów”); Napaść żolnierzy na Polaków, „Gazeta Toruńska”, nr 4, 6 I 1920, s. 1. 
wych wiecach i tworząc oddziały Grenzschutzu-Ost (wiosną 1919 r. około 60 tysięcy żołnierzy). Ich postawę streszczała wypowiedź nadburmistrza Hansa Sahma (1877-1939): „Hände weg von Danzig”47, oraz antypolskie rozporządzenia prezydenta Prus Zachodnich, Ernsta von Jagowa (1853-1930), niepozwalające na rozwój polskich instytucji i noszenie polskich symboli, co dałoby Niemcom prowokacyjny pretekst do likwidacji polskiego ruchu niepodległościowego, o czym raportował z Gdańska polski urzędnik do premiera Ignacego Jana Paderewskiego:

Od miesiąca przeszło jesteśmy świadkami gorączkowych przygotowań wojennych: miasto całe i okolice są przepełnione wojskiem, na polach podmiejskich na łęgach wiślanych dzień w dzień odbywają się ćwiczenia wojskowe [...].

W celu podjęcia nastroju wśród ludności niemieckiej od pewnego czasu poczynione są starania i stosowane są wszelkie możliwe środki dla wywołania ruchawki wśród Polaków i Kaszubów, zamieszkujących wybrzeża bałtyckie od Gdańska aż ku Malborkowi.

Działacze miejscowi mówili mi, że z trudem udaje się im powstrzymać wrzenie wśród ludności polskiej, szczególnie wśród Kaszubów ${ }^{48}$.

Polacy w Gdańsku, podobnie jak na Pomorzu wiązali nadzieje powstańcze z pojawieniem się „Błękitnej Armii”49. Przybycie to - zbrojne, do którego ostatecznie nie doszło - zwiastowała kolportowana w mieście ulotka z 15 kwietnia 1919 r.:

Jenerał Haller ląduje w Gdańsku! Rodacy! Wielka chwila się zbliża!

Nareszcie bije godzina istotnego zjednoczenia Polski. Uczyni to siła zbrojna! Najoporniejszy wróg nasz, Prusacy, muszą ustąpić z ziem polskich dotąd przez nich gnębionych. Zmusi ich do tego Jenerał Haller. [...] Lądując w Gdańsku Jenerał Haller zdobył nam dostęp do morza ${ }^{50}$.

${ }^{47}$ A. Drzycimski, Polacy w Wolnym Mieście Gdańsku w latach 1920-1933, Wrocław 1978, s. 20; H. Sahm (w 1915 r. w Warszawie) wpisany był przez władze II RP na listę przestępców wojennych: S. Mikos, Wolne Miasto Gdańsk a Liga Narodów 1920-1939, Gdańsk 1979, s. 25-26; Powrót. Dokumentacja, s. 40-41, 43, 48 (protest S. Łaszewskiego: słowa Sahma to „hasło bezpodstawne i bezcelowe").

${ }^{48}$ M. Jałowiecki do I. Paderewskiego, 19 maja 1919, cyt. za: tamże, s. 157-158.

${ }^{49}$ S. Mikos, Wolne Miasto Gdańsk w okresie rząów parlamentarnych (1920-1933), w: Historia Gdańska, red. E. Cieślak, t. IV, cz. 2 (1920-1945), Sopot 1999, s. 36. H. Sahm uczestniczył w Spa 4 kwietnia 1919 r. w konferencji z marsz. Ferdynandem Fochem, efektem której była umowa o przejeździe armii gen. J. Hallera nie przez Gdańsk lecz Niemcy - TENże, Wolne Miasto Gdańsk a Liga Narodów, s. 27; P. Olstowski, Organizacja Wojskowa, s. 121 (brak koordynacji działań władz polskich, tańszy przejazd kolejowy niż morski); „[...] rząd polski nie upomniał się pisemnie i oficjalnie o jego i jego wojsk przejazd do Polski”: Archiwum polityczne, s. 45-46.

${ }^{50}$ Cyt. za: C. Skonka, Chcemy zachować skarby, Sopot 1992, s. 25-26. 
Jednym z głównych organizatorów planowanego powstania był dr Franciszek Kręcki. To w lokalu jego firmy działał nielegalnie Podkomisariat Naczelnej Rady Ludowej, a sam Kręcki stanął na czele tzw. decernatu wojskowego; to z jego polecenia podwładni, m.in. rodzeństwo Wanda i Stefan Waliccy przewozili na trasie do i z Poznania tajne dokumenty i pieniądze. Magazyn broni znajdował się w domu i drukarni rodziny Czyżewskich, których ojciec, Józef (1857-1935), zaangażował się w działalność niepodległościową ${ }^{51}$. Drukarnia Jana Kwiatkowskiego (18691941), wydawcy „Gazety Gdańskiej”52, stała się w 1918 r. siedzibą Rady Żołnierskiej kierowanej przez Edmunda Jonasa (1893-1940). Ten wybitny działacz polski mając dostęp do sztabu XVII Korpusu Armijnego wojsk niemieckich w Gdańsku prowadził, w ramach OWP, antyniemiecką działalność wywiadowczą ${ }^{53}$. W drukarni Kwiatkowskiego spotykali się również działacze Związku Zjednoczenia Zawodowego Polskiego, którzy, podobnie jak Antoni Lendzion (1888-1940), należeli do obu organizacji i przygotowywali powstanie.

O powstaniu zbrojnym i stworzeniu separatystycznego państwa niemieckiego (ein Oststaat) myśleli także Niemcy ${ }^{54}$. Ulegli jednak wobec postanowień „dyktatu” wersalskiego, który narzucił obu zwaśnionym stronom kompromisowe rozwiązanie w postaci Wolnego Miasta Gdańska (WMG) ${ }^{55}$. W złożonej sytuacji międzynarodowej, gdy ścierały się interesy brytyjskie i francuskie ${ }^{56}$, gdy niepewne było wsparcie

${ }^{51}$ G. Danielewicz, M. KoprowsKa, M. Walicka, Polki w Wolnym Miéście Gdańsku, Gdańsk 1985, s. 30-31, 39.

${ }^{52}$ A. Romanow, ,, Gazeta Gdańska” w latach 1891-1939, Gdańsk 2017, s. 106 (przy ul. Vorstädtischer Graben 49 mieścił się Podkomisariat NRL); s. 214-215 (niemiecki napad na redakcję); (niemieckojęzyczny tygodnik „Polnische Warte” informował o sytuacji z polskiego punktu widzenia - s. 221).

53 J. WóJCicKi, Wolne Miasto Gdańsk 1920-1939, Warszawa 1976, s. 96.

${ }^{54}$ B. LeśnOdORSki, Plebiscyt na Warmii i Mazurach w 1920 r., w: Szkice z dziejów Pomorza. Pomorze na progu dziejów najnowszych, red. T. Cieślak, G. Labuda, S. Hoszowski, Warszawa 1961, s. 444 (w maju i czerwcu 1919 r. w Malborku i Berlinie konferowano nad projektem „bałtyckiej Szwajcarii"); Pomorze Gdańskie i ziemia chetmińska w drodze do Niepodległej (1914-1920), red. Z. Girzyński, I. Hałagida, J. Kłaczkow, Torun 2019, s. 122-123.

${ }^{55}$ Sensacyjny dokument $z$ archiwów niemieckich, „Nadwiślanin”, nr 110, 6 XI 1919, s. 1 - o planach wojny z Polską w czerwcu 1919 r.; „Gazeta Toruńska”, nr 155, 1 VII 1919, s. 1-2 - o planach przekształcenia Prus Wschodnich w powiązane unią lub autonomią z Polską państwo pisał Roman Dmowski w 1918 r.: R. WAPIŃsKi, Świadomość polityczna, s. 201; Archiwum polityczne, s. 126-127; Polska w latach 1918-1939. Wybór, s. 60-61 („,może istnieć niezależnie jako republika pod protektoratem Ligi Narodów”).

56 „Jeżeli Niemcy przejdą do spartakizmu, to nieuchronnie połączą się z Rosją, a jeśli to się stanie, to rewolucja bolszewicka ogarnie całą wschodnią Europę" - głosił David Lloyd George 25 marca 1919 r. - cyt. za: W. ZAJEwsKI, Wpływ opinii publicznej na decyzje konferencji pokojowej w Paryżu, „Litery”, 8(1969), nr 11, s. 32. Profesor dodaje: „Trafnie pisze francuski historyk dyplomacji P. Renouvin, że „formuly wilsonowskie respektowano tylko w takim stopniu, w jakim odpowiadały one zwycięzcom" (tamże, s. 32); „P[an] Dmowski twierdzi, że stanowisko Anglików znacznie się polepszyło. Sokolnicki, który wrócił wczoraj z Londynu, patrzy pesymistycznie na Gdańsk" (Archiwum polityczne, s. 44). 
amerykańskie ${ }^{57}$, rząd polski musiał w sposób bardzo poufny i nieformalny wspierać Polonię gdańską w jej dążeniu do połączenia z Rzeczypospolitą. Za zezwoleniem Naczelnika Państwa Józefa Piłsudskiego utworzono urząd Generalnego Delegata Ministerstwa Aprowizacji na miasto Gdańsk, działający pod patronatem Amerykańskiej Administracji Pomocy - Misji dla Polski (American Relief Administration, Mission for Poland). Na jej czele stał Mieczysław Jałowiecki (1876-1962), mianowany wkrótce przez premiera Ignacego Jana Paderewskiego Delegatem Rządu Polskiego $^{58}$. Oficjalnie zajmował się zaopatrzeniem w żywność, choć i na tym polu Prezydent i Senat WMG czynili trudności; faktycznie zaś wspierał polskie dążenia zjednoczeniowe, tym bardziej że wspomagał go ekspert wojskowy, gen. (admirał) Michał Borowski (1872-1939). Działania te musiały mieć charakter ściśle tajny ze względu na postawę Niemców, którzy zdecydowanie optowali za utrzymaniem Gdańska w granicach przedwojennych Niemiec; Amerykanów, powracających do tradycyjnej polityki izolacjonizmu (choć amerykańska opinia publiczna uznała decyzje konferencji w Spa za poniżające dla Polski); proniemiecko nastawionego premiera Wielkiej Brytanii Davida Lloyda George'a i wymuszone oficjalnie neutralne stanowisko Polski, która nie podpisała zawieszenia broni z Niemcami. Nad prawidłową realizacją pomocy żywnościowej mogły zatem czuwać USA (do końca 1919 r. wyładowano w porcie gdańskim przeszło 350 tysięcy ton żywności). Jałowiecki skompletował grupę 150 polskich pracowników, których zadań nie ograniczał tylko do przeładunku i transportu towarów, lecz, mimo szykan niemieckich, do zakupu nieruchomości mających stanowić własność RP.

\begin{abstract}
Mimo bardzo ścisłej opieki, którą zapewne władze niemieckie otaczały naszą Delegację, uważałem za konieczne nawiązać kontakt z polskim społeczeństwem w Gdańsku [szczególnie z działaczami] z Polskiej Rady Ludowej. Któregoś wieczora udałem się zachowując ścisłe incognito do mieszkania ś.p. pana dr. J. Wybickiego, gdzie miałem możność zetknąć się z dr. [Leonem] Kręckim [...]. W owych chwilach ci dwaj działacze, żyli jednak pod stałą grozą aresztu ze strony władz niemieckich i komunikować się z nimi mogłem najczęściej w nocy. [...] Dzięki pomocy tych Panów miałem możność zaangażowania wyłącznie Polaków zarówno do pracy w porcie, jak i do naszych biur ${ }^{59}$.
\end{abstract}

57 „If the Peace Conference confirms Prussia's title to Danzig, the war has been fought in vain" (J.F. Smulski do T.W. Wilsona, Archiwum polityczne, s. 126-127).

${ }^{58}$ S. Mikos, Wolne Miasto, s. 42-43; TENŻE, Wolne Miasto Gdańsk a Liga Narodów, s. 28. Amerykanie z powodu trudności w wymawianiu polskiego nazwiska mówili do Jałowieckiego „Yellow whisky”: M. JAŁOWIECKI, Wspomnienia, raporty i sprawozdania z Gdańska (1919-1920), oprac. Z. Machaliński, Gdańsk 1995, s. 59.

${ }^{59}$ Tamże, s. 74-75; S. Miкos, Wolne Miasto Gdańsk a Liga Narodów, s. 29. 


\section{POLACY Z POMORZA W WALCE Z NAJAZDEM BOLSZEWICKIM W 1920 ROKU}

Po włączeniu Pomorza Gdańskiego w granice II RP utworzono w Grudziądzu Dowództwo Okręgu Generalnego „Pomorze” z gen. Kazimierzem Raszewskim (1864-1941), a następnie gen. Bolesławem Roją (1876-1940) na czele. W lipcu 1920 r. Marszałek Józef Piłsudski powołał w obliczu zagrożenia najazdem sowieckim Zachodnią Straż Obywatelską, a nowy wojewoda pomorski Jan Brejski (18631934) - dawny filomata, dziennikarz i parlamentarzysta zasłużony dla repolonizacji Pomorza $^{60}$, wydał niezbędną odezwę:
Pomorzanie do broni!
Pomorzu grozi najazd wroga.
Dzicz bolszewicka, o których okrucieństwach dochodziły do nas od dłuższego czasu głuche wieści, zagraża naszej dzielnicy mordem i pożogą. Kilka pogranicznych gmin Pomorza, wysuniętych najdalej na południowy wschód, już miały sposobność zapo- znania się $\mathrm{z}$ bestialstwem bolszewików.
Pomorzanie! Czy zostawimy braci naszych pod knutem dziczy azjatyckiej? [...]
Kto w Boga wierzy, komu nieobojętne bezpieczeństwo rodziny, kto dobytku swojego nie chce wydać na zatracenie, niech chwyta za broń!
Toruń, dnia 15 sierpnia 1920 roku $^{61}$.

Strategicznie ważnym punktem okazała się stacja kolejowa Działdowo, na linii kolejowej Gdańsk-Warszawa: Polakom stwarzała dostęp do pomocy zaopatrzeniowej z Gdańska, Rosjanom z 3. Korpusu Kawalerii Gaja otwierała drogę na Zachód, pozwalała wyjść na tyły przeciwnika i połączyć się z Niemcami. Po pierwszych porażkach Grupy Operacyjnej „Działdowo”: pod Mławą (8-10 lipca 1920), Działdowem (12-13 lipca), Brodnicą (15 sierpnia) zachodziła obawa nie tylko o utratę Grudziądza, Bydgoszczy i Torunia, lecz również o zagrożenie granicy polskiej przez agresję niemiecką, tym bardziej że jednocześnie z ruchami wojsk sowieckich rozpoczęły się prowokacje niemieckie, np. zajęcie stacji kolejowej Biskupiec (17 sierpnia), atak na polską placówkę przy moście w Kwidzynie (19 sierpnia), koncentracja wojsk pod Babimostem i Sulmierzycami (20 sierpnia $)^{62}$. Ale bitwa pod Brodnicą stoczona 18 sierpnia 1920 r. w ramach szeroko zakrojonej ofensywy polskiej, bę-

\footnotetext{
${ }^{60}$ P. Olstowski, Wojewodowie pomorscy w latach II Rzeczypospolitej (1920-1939). Szkic do portretu zbiorowego, „Zapiski Historyczne”, 80(2015), z. 3, s. 274-276. Jan Brejski - wojewoda w latach 1920-1924.

${ }^{61}$ W. ZaWADZKi, Pomorze 1920, Warszawa 2015, s. 152.

${ }^{62}$ Tamże, s. 144-145.
} 
dąca sukcesem Grupy Operacyjnej płk. Witolda Aleksandrowicza (1875-1955) w powiązaniu z atakiem 5 Armii na Ciechanów, uratowała Pomorze i zmusiła wojska sowieckie do odwrotu i przekroczenia granicy Prus Wschodnich, gdzie znalazły schronienie ${ }^{63}$.

\section{EPILOGI}

\section{PRZYKŁAD LOSÓW MNIEJSZOŚCI POLSKIEJ ZAMIESZKAŁEJ PO NIEMIECKIEJ STRONIE GRANICY}

Konferencja pokojowa w Paryżu pozostawiła część ziem pomorskich w granicach Republiki Weimarskiej. Jeszcze w trakcie trwania obrad władze niemieckie chcąc nawiązać do zaborczej tradycji sprawowania kontroli administracyjnej nad utraconymi na rzecz Polski terenami, nadały przyznanemu sobie terytorium rewizjonistyczną nazwę Die Provinz Grenzmark Posen-Westpreussen. Byłoby to w oczach niemieckiej opinii publicznej ,mobilizujące świadectwo przeszłości i nadzieja na przyszłość", tym bardziej że Niemcy w Dwudziestoleciu marzyli o powrocie do granic państwowych z 1914 r. ${ }^{64}$ Nowy okręg ukształtowany w latach 1919-1922, istniał do 1933 r. i obejmował m.in. część powiatów: chojnickiego, człuchowskiego, złotowskiego, trzcińskiego, międzyrzeckiego, babimojskiego ze stolicą w Pile. Urzędnicy, w większości przeniesieni z Bydgoszczy, mieli jako kadra oczekiwać na rychły upadek polskiego „sezonowego państwa”, by rychło wrócić na utracone ziemie. Sytuacja Polaków mieszkających np. w powiecie złotowskim była w $1920 \mathrm{r}$. niezwykle ciężka. Niemcy, stosując wypróbowane, bismarckowskie metody kolonizacyjne, zmuszali Polaków do sprzedaży ziemi (ale z reguły bez inwentarza żywego) i wyjazdów do Polski, przeprowadzano rewizje. „Pułkownik angielski prezydent podkomisji granicznej północnej oświadczył mi - raportował w marcu $1920 \mathrm{r}$. do Poznania polski członek Komisji Granicznej - że wjeżdżając do pierwszej wsi położonej za kordonem niemieckim (Podrużna) wyniósł wrażenie, że wjeżdżał do obozu jeńców..." ${ }^{65}$. Szykany dotknęły miejscową Radę Ludową, która wysłała delegację na obrady konferencji w Spa, bezskutecznie żądając korekty granicy ${ }^{66}$.

\footnotetext{
${ }^{63}$ Tamże, s. 152; G. Łukomski, B. Polak, M. WrzoseK, Wojna polsko-bolszewicka 1919-1920, t. II (marzec - październik 1920 r.), Koszalin 1990, s. 120-122, 124-125.

${ }^{64}$ J. WĄSICKI, Prowincja Grenzmark Posen-Westpreussen, „Roczniki Historyczne”, 31(1965), s. 64.

${ }_{65}$ Tamże, s. 93.

${ }^{66}$ Tamże, s. 94-95.
} 


\section{UTWORZENIE WOJEWÓDZTWA POMORSKIEGO. STOSUNKI POLSKO-GDAŃSKIE. ZAŚLUBINY POLSKI Z MORZEM}

Na mocy postanowień traktatu wersalskiego, w zapisach dotyczących dostępu Polski do Bałtyku Rzeczpospolita uzyskała 15843 km kw. powierzchni Pomorza Gdańskiego, a na Powiślu miano przeprowadzić plebiscyt ${ }^{67}$. Pierwszym wojewodą pomorskim z siedzibą w Toruniu został dr Stanisław Łaszewski ${ }^{68}$. Dnia 17 października 1919 r. objął stanowisko wojewody pomorskiego $\mathrm{w}$ randze podsekretarza stanu, a następnie rozpoczął urzędowanie w Toruniu (od stycznia do lipca 1920 r.). Pracował w bardzo trudnych, pionierskich wręcz warunkach, ale pozostawił po sobie bardzo wdzięczną pamięć społeczeństwa, które w 1925 r. ufundowało ku jego czci pomnik w Toruniu. Województwo składało się z przyznanych Polsce powiatów, m.in. puckiego, starogardzkiego, grudziądzkiego, tucholskiego oraz w większości kościerskiego, kartuskiego, wejherowskiego, chojnickiego; dołączono również z Prus Wschodnich Działdowo. Rozpoczęto tworzenie komisarycznych samorządów, a na ich czele postawiono jako starostę krajowego dr. Józefa Wybickiego. Spełniły się zatem marzenia, by w niepodległej Polsce miejscowa ludność miała możność „,spożywania owoców swej pracy i możność życia kulturalnego - a wreszcie udziału w rządach najukochańszym krajem" ${ }^{69}$. Nastąpiły wyjazdy Niemców, których liczba zmniejszyła się o około 200 tys. osób i w 1921 r. nie przekraczała $11 \%$ ogółu mieszkańców województwa ${ }^{70}$.

Od początku źle ułożyły się stosunki II RP z Wolnym Miastem Gdańskiem; pogarszała się też sytuacja Polaków - mieszkańców WMG wobec wrogości wobec nich władz WMG. Konwencja paryska z listopada 1920 r. zmniejszała prawa Polski w Gdańsku, a nawet okazała się sprzeczna z artykułami traktatu wersalskiego (np. nowo powołana Rada Portu i Dróg Wodnych odbierała częściowo Polsce prawa przyznane w art. 104 traktatu wersalskiego). Polskich mieszkańców Gdańska na mocy art. 33 konwencji zaczęto traktować wbrew zapisom z Wersalu jako mniejszość narodową ${ }^{71}$. Tymczasem urząd Delegata Rządu Polskiego przekształcił się w urząd Komisarza Generalnego Rzeczypospolitej Polskiej w Gdańsku (dr Maciej Biesiadecki od stycznia 1920 r.), zaś na bazie Podkomisariatu Naczelnej Rady

\footnotetext{
${ }^{67}$ W. ZaWAdZKI, Pomorze, s. 27; R. WaPIŃski, Lata nadziei, s. 428.

${ }^{68}$ P. Olstowski, Wojewodowie pomorscy, s. 275, 279.

${ }^{69}$ Wypowiedź pisarki Marii Dąbrowskiej, Powrót Polski nad Battyk 1920-1945. Antologia tekstów historycznych, oprac. M. Drozdowski, Warszawa 1997, s. 48.

${ }^{70}$ R. WAPIŃsKi, Lata nadziei (1918-1939), w: Dzieje Pomorza Nadwiślańskiego, s. 428-429, 448.

${ }^{71}$ A. Drzycimski, Polacy, s. 33-34; Polska w latach 1918-1939. Wybór tekstów, s. 178-180.
} 
Ludowej utworzono Gminę Polską, a jej pierwszym prezesem w 1921 r. został dr Franciszek Kubacz ${ }^{72}$.

Trudności, jakie władze WMG stawiały Polsce, np. hamując rozładowanie brytyjskiego statku „Tryton” z dostawami broni dla walczącej w 1920 r. z Rosją Sowiecką Polski sprawiły, że Sejm RP przyjął ustawę o budowie portu w Gdyni, poprzedzoną raportem inż. Tadeusza Wendy (1863-1948) wyliczającego zalety przyszłej lokalizacji portu handlowego i wojennego ${ }^{73}$. Trawestując nieco wypowiedź Marii Dąbrowskiej można powiedzieć, że uzyskanie „przystępu do Morza Bałtyckiego stało się jednym z najważniejszych tryumfów wyzwalającej się Polski" "74.

Dnia 10 lutego 1920 r. w Pucku doszło do uroczystości zaślubin Polski z morzem, choć nie obyło się bez nieprzewidzianych trudności. Padał deszcz i wiał silny wiatr, zdezelowana lokomotywa jechała dwa razy dłużej niż zwykle. Okolicznościowe kazanie wygłosił kapelan, ksiądz Józef Wrycza, który wspomniał o cierpieniach ludu kaszubskiego pod pruskim zaborem i zapewnił, że Polacy nie ustaną w wysiłkach póki Gdańsk - „ten klucz do morza nie spocznie w skarbcu polskim"75. Wbrew legendzie utrwalonej na obrazie Wojciecha Kossaka Haller nie wjechał konno w morze, tylko wrzucił jedną z platynowych obrączek, wręczonych mu w Gdańsku przez dr. Wybickiego do przerębli (drugą nosił na palcu do końca życia). Zaczepiła się jednak o lodową krę i trzeba było pomocy kilku Kaszubów, by zniknęła w głębinach morza ${ }^{76}$.

\begin{abstract}
Pamiętam - wspominał gen. Józef Haller - jak pierścień potoczył się po tafli lodu, by wnet zniknąć w morzu. Wyrwało się kilku młodych rybaków chcących go chwycić, a gdy powracali - na moje zapytanie, czy chwycili go - odpowiedzieli: nie, pan generał, ale będziemy go mieli w Szczecinie ${ }^{77}$.
\end{abstract}

W ślad za generałem i ułanami brzeg morza przestąpiła delegacja rządu i sejmu oraz dziennikarze ${ }^{78}$. Następnego dnia, 11 lutego 1920 r. delegacja polskiego rządu i sejmu wypłynęła w Wielkiej Wsi (późniejszym Władysławowie) na pokładzie

${ }^{72}$ S. Mikos, Historia Gdańska, s. 43, 47.

73 A. Zechentner, Złapać morski oddech, „Biuletyn Instytutu Pamięci Narodowej”, nr 12 (2018), s. 10.

${ }^{74}$ Powrót Polski, s. 99 (w oryginale: będzie jednym...).

${ }^{75}$ Z uroczystości objęcia morza przez Polskę, „Gazeta Gdańska”, nr 35, 14 II 1920, s. 1.

${ }^{76}$ M. WaŃKowicz, Walczacy gryf, Warszawa 1975, s. 56-57; Uroczystość w Pucku, „Gazeta Gdańska”, nr 34, 13 II 1920, s. 1; Polskie morze, „Gazeta Toruńska”, nr 37, 15 II 1920, s. 2.

77 Cyt. za: Z uroczystości objęcia morza przez Polskę, „Gazeta Gdańska”, nr 35, 14 II 1920, s. 1; J. Haller, Pamiętniki, oprac. M. Pilecka, Łomianki 2015, s. 249.

${ }^{78}$ Kaszubi żartowali, „iż w życiu nie widzieli w Bałtyku naraz tylu bałwanów”: B. SKaradziŃsKi, Sąd boży 1920 roku, Warszawa 1995, s. 134. 
kutra „Seestern” („Gwiazda Morska”), pod biało-czerwoną banderą na pełne morze by zaświadczyć, że Polska powróciła nad Bałtyk ${ }^{79}$.

Walka o powrót Pomorza Gdańskiego do Macierzy w latach 1918-1920 zakończyła się względnym sukcesem: tylko $62 \%$ obszaru znalazło się w granicach II Rzeczypospolitej. Dążenia Polaków - mieszkańców Gdańska o włączenie ich miasta do Polski nie powiodły się. W Wolnym Mieście prężnie działała Gmina Polska zmagająca się z wrogością lokalnych władz. Symbolem działań Organizacji Wojskowej Pomorza stała się przyznawana uczestnikom konspiracji Odznaka OWP, którą otrzymał również ksiądz ppłk Józef Wrycza, a 13 osób odznaczono krzyżami Virtuti Militari. Słup pamiątkowy z polskim orłem wbity w brzeg polskiego morza 10 lutego 1920 r. zaświadczał, iż od tej pory znad Bałtyku wieje na całą II RP polski „wiatr od morza”.

Wysiłek zbrojny Pomorzan w wojnie polsko-bolszewickiej wliczając ochotników, Straż, 16 Dywizję Piechoty wyniósł około 40 tys. ludzi ${ }^{80}$. Integracja Pomorza Gdańskiego z II RP mimo początkowych trudności (przeważała gospodarka rolna i leśna, przemysł spożywczy i drzewny stanowił 70\% zakładów i $50 \%$ robotników ${ }^{81}$ następowała szybko, zwłaszcza dzięki budowie Gdyni - polskiemu „oknu na świat”»2. „Chcemy trzymać się morza! Jest to potrzebą i koniecznością niezłomną państwa i całego społeczeństwa - pisał Eugeniusz Kwiatkowski - A ponad to wszystko najważniejsze jest, że dziś Gdynia stanowi własność duchową i własność pracy, wysiłku, z takim niezmierzonym trudem zebranego kapitału całego społeczeństwa polskiego"83 - w słowach tych niewątpliwie słychać hołd złożony pokoleniu walczącemu o niepodległość i rozwój II RP.

BIBLIOGRAFIA

\section{ŹRÓDŁA DRUKOWANE}

Archiwum polityczne Ignacego Paderewskiego, oprac. W. Stankiewicz, A. Piber, t. II (1919-1921),

Wrocław 1974.

79 J. Haller, Pamiętniki, s. 251; Powrót Polski, s. 133-134; C. Obracht-Prondzyński, K. Korda, Powrót Pomorza, s. 86.

${ }^{80}$ W. ZaWAdZKi, Pomorze, s. $72-73$.

${ }^{81}$ R. WAPIŃSKI, Pomorze w latach Dwudziestolecia (1920-1939), w: Pomorze Gdańskie. Szkice polityczno-gospodarcze, t. I, Gdańsk 1965, s. 145-148.

${ }^{82}$ W 1926 r. obroty towarowe portu w Gdyni wynosily 404561 ton, w 1928 r. - 1957769 ton, w 1938 r. 9311332 tony, tamże, s. 147.

${ }^{83}$ E. KwiatKowski, Powrót Polski nad Battyk, 1930, cyt. za: A. ZECHENTER, Gdynia. Zlapać morski oddech, „Biuletyn IPN”, 2018, nr 12, s. 11. 
Dembieński J. ks., Radości mało - goryczy dużo. Pamiętnik Pomorzanina z lat 1879-1920, oprac. A. Bukowski, Warszawa 1985.

Haller J., Pamiętniki, oprac. M. Pilecka, Łomianki 2015.

JAŁOWIECKI M., Wspomnienia, raporty i sprawozdania z Gdańska (1919-1920), oprac. Z. Machaliński, Gdańsk 1995.

Lienau O., Die Geschichte der Studentenkompanie auf dem Hagelsberg zu Danzig, Danzig 1929.

Polska w latach 1918-1939. Wybór tekstów źródłowych do nauczania historii, red. W. Wrzesiński, oprac. K. Kawalec, L. Smołka, W. Suleja, Warszawa 1986.

Powrót. Dokumentacja ustanowienia suwerenności polskiej na Pomorzu w latach 1918-1920, wybór J. Bełkot, M. Wojciechowski, Toruń 1988.

Powrót Polski nad Baltyk 1920-1945. Antologia tekstów historycznych, oprac. M. Drozdowski, Warszawa 1997.

Źródła, w: C. Obracht-ProndzyŃski, K. Korda, Powrót Pomorza w granice Rzeczypospolitej. W setna rocznicę 1920-2020, Gdańsk 2020.

PRASA

„Gazeta Gdańska” 1919-1920

„Gazeta Toruńska” 1919-1920

„Nadwiślanin” 1919-1920

\section{OPRACOWANIA}

Borzyszkowski J., Gdańsk i Pomorze w XIX i XX wieku, Gdańsk 1999.

Borzyszkowski J., Ideat państwa polskiego - marzenia Pomorzan a rzeczywistość w 1920 r., w: Pomorskie drogi do Niepodległej, red. J. Borzyszkowski i C. Obracht-Prondzyński, Gdańsk 2018.

Borzyszkowski J., O historii literatury kaszubskiej i jej twórcach, Gdańsk 2011.

Borzyszkowski J., Partyzantka Borów Tucholskich XX w. - mity a rzeczywistość, w: Ludzie, idee, wojny. Studia z dziejów Europy środkowo-wschodniej, red. T. Kawski, J. Maciejewski, Bydgoszcz 2009.

Brzoza C., Polska w czasach niepodległości i II wojny światowej (1918-1945), w: Wielka historia Polski, red. S. Grodziski [i in.], t. V, cz. 1, Warszawa-Kraków 2003.

Brzoza J., Polski rok 1919, Londyn 1988.

Byкowska S., Elementy polskiej tożsamości narodowej na Pomorzu od połowy XIX wieku do powstania Drugiej Rzeczypospolitej, „Słupskie Studia Historyczne”, 2012, nr 18.

CieŚlak T., Przeciw pruskiej przemocy. Walka o ziemię na Pomorzu na przełomie XIX i XX w., Warszawa 1959.

Danielewicz G., Koprowska M., Walicka M., Polki w Wolnym Mieście Gdańsku, Gdańsk 1985.

Drzycimski A., Polacy w Wolnym Mieście Gdańsku w latach 1920-1933, Wrocław 1978.

Dzieje Pomorza Nadwiślańskiego od VII wieku do 1945 roku, red. W. Odyniec, Gdańsk 1978.

Hirsch M., Nieustraszeni. 66. Kaszubski Pułk Piechoty im. Marszałka Józefa Piłsudskiego 1919-1939, Gdańsk 2017.

Historia Gdańska, red. E. Cieślak, t. IV, cz. 2 (1920-1945), Sopot 1999.

Korda K., Ks. ppłk Józef Wrycza (1884-1961). Biografia historyczna, Gdańsk 2016.

KukIEL M., Dzieje Polski porozbiorowe 1795-1921, Paryż 1984. 
LeŚnOdorski B., Plebiscyt na Warmii i Mazurach w 1920 r., w: Szkice z dziejów Pomorza. Pomorze na progu dziejów najnowszych, red. T. Cieślak, G. Labuda, S. Hoszowski, Warszawa 1961.

Lienau O., Die Geschichte der Studentenkompanie auf dem Hagelsberg zu Danzig, Danzig 1929.

Łukomski G., Polak B., Wrzosek M., Wojna polsko-bolszewicka 1919-1920, t. II (marzec-październik 1920 r.), Koszalin 1990.

Mıкоs S., Wolne Miasto Gdańsk w okresie rządów parlamentarnych (1920-1933), w: Historia Gdańska, red. E. Cieślak, t. IV, cz. 2 (1920-1945), Sopot 1999.

Mikos S., Wolne Miasto Gdańsk a Liga Narodów 1920-1939, Gdańsk 1979.

NowaK A., Rozważania o niepodległości 1018-1918-2018, „Arcana”, 2018, nr 143.

Obracht-Prondzyński C., Korda K., Powrót Pomorza w granice Rzeczypospolitej. W setna rocznice 1920-2020, Gdańsk 2020.

Olstowski P., Organizacja Wojskowa Pomorza (1918-1920). Polska konspiracja zbrojna w okresie poprzedzajacym powrót Pomorza do Polski. Pytania i postulaty badawcze, „Rocznik Toruński”, 46 (2019).

Olstowski P., Wojewodowie pomorscy w latach II Rzeczypospolitej (1920-1939). Szkic do portretu zbiorowego, „Zapiski Historyczne”, 80 (2015), z. 3.

Osterhammer J., Historia XIX wieku. Przeobrażenie świata, tłum. I. Drozdowska-Broering [i in.], Poznań 2013.

Pomorze Gdańskie i ziemia chetmińska w drodze do Niepodległej (1914-1920), red. Z. Girzyński, I. Hałagida, J. Kłaczkow, Toruń 2019.

Rezmer W., Militarne szanse powstania na Pomorzu, w: Problemy militarne na Pomorzu w latach 1914-1989, red. A. Stachura, Stupsk 2002.

Romanow A., ,, Gazeta Gdańska” w latach 1891-1939, Gdańsk 2017.

SkaradziŃski B., Sąd boży 1920 roku, Warszawa 1995.

Skonka C., Chcemy zachować skarby, Sopot 1992.

Skonka C., Wizyta I. J. Paderewskiego w Gdańsku, „Pieśń Skrzydlata”, 18(2010), nr 2.

WaŃKOwicz M., Walczacy gryf, Warszawa 1975.

WAPIŃSki R., Lata nadziei (1918-1939), w: Dzieje Pomorza Nadwiślańskiego od VII wieku do 1945 roku, red. W. Odyniec, Gdańsk 1978.

WaPıŃski R., Pomorze Nadwiślańskie w okresie II Rzeszy (1871-1918), w: Dzieje Pomorza Nadwiślańskiego od VII wieku do 1945 roku, red. W. Odyniec, Gdańsk 1978.

WaPIŃski R., Pomorze w latach Dwudziestolecia (1920-1939), w: Pomorze Gdańskie. Szkice polityczno-gospodarcze, t. I, Gdańsk 1965.

WaPIŃski R., Świadomość polityczna w Drugiej Rzeczypospolitej, Łódź 1989.

WąSICKi J., Prowincja Grenzmark Posen-Westpreussen, „Roczniki Historyczne”, 31(1965).

Wojciechowski M., Dwie koncepcje powrotu Pomorza Gdańskiego do Polski w latach 1918-1920, „Zapiski Historyczne”, 35 (1970), z. 1.

Wojciechowski M., Ruch polski na Pomorzu Gdańskim w latach pierwszej wojny światowej (19141918), „Zapiski Historyczne”, 39 (1974), z. 3.

WóJCicki J., Wolne Miasto Gdańsk 1920-1939, Warszawa 1976.

WrZesiński W., Kresy czy pogranicze? Problem ziem zachodnich i pótnocnych w polskiej myśli politycznej XIX i XX w., w: Między Polską etniczna a historyczna, red. W. Wrzesiński (seria: Polska myśl polityczna XIX i XX wieku, t. 6), Wrocław 1988. 
ZAJEwski W., Wpływ opinii publicznej na decyzje konferencji pokojowej w Paryżu, „Litery”, 8 (1969), nr 11.

ZaWADZKi W., Pomorze 1920, Warszawa 2015.

Zechenter A., Złapać morski oddech, „Biuletyn Instytutu Pamięci Narodowej”, 2018, nr 12.

\title{
POMERANIANS \\ IN THE FIGHT FOR THE RETURN OF GDANSK-POMERANIA TO POLAND \\ 1918-1920
}

\begin{abstract}
The "long" 19th century (1772-1920) passed in Pomerania-Gdansk under the Prussian-German invaders. In spite of Bismarck's germanization, modern polish national bassed on the traditions of the struggle for independence (for example Napoleonic Free City of Gdańsk, Springtide of Nations 1848 and polish Uprisings 1830, 1863) and positivist slogans which influenced the attitudes of Poles in the years 1918-1920. On the merger of Pomerania-Gdansk - Pomerania-on the Vistula - Western Prussia (germ. 'Westpreussen') with Poland regaining independence was determined by strongties with the Greater Poland Uprising and the decisions of the peace conference in Paris (1919). Despite the ban of fighting against Pomerania issued by the Supreme People's Council (Naczelna Rada Ludowa), various underground groups led here, including the Pomeranian Military Organization (Organizacja Wojskowa Pomorza), fighting with the German Grenzschutz-Ost (germ. 'border paramilitary units'), preparing the uprising in Gdansk in the event of the appearance of the "Blue Army" (Polish Army in France) gen. Joseph Haller's, forming a guerilla in Bory Tucholskie (pol. Forrest of Tuchola). The conspirators took part in the war with Soviet Russia in 1920 and the symbol of their victory became the "marriage" of Poland with the Baltic Sea on February 10, 1920.
\end{abstract}

Keywords: Pomerania-Gdansk; the Peace Conference in Paris; Greater Poland Uprising; the Pomerania Military Organization; the Free City of Gdansk; "marriage" of Poland with the Baltic Sea. 